\title{
Generation and Characterization of Anti-Leptin Antisera against Synthetic Peptides and Recombinant Protein
}

\author{
Toru TAKAHASHI ${ }^{1{ }^{\#},}$ Kei IMAI ${ }^{1{ }^{\#}}$ and Kazuyoshi HASHIZUME²) \\ ${ }^{1)}$ National Institute of Agrobiological Sciences, Tsukuba, Ibaraki 305-8602, \\ ${ }^{2)}$ Iwate University, Morioka, Iwate 020-8550, Japan \\ \#Present: National Livestock Breeding Center, Nishigo, Fukushima 961-8511, Japan
}

\begin{abstract}
The objective of this study was to generate antisera against recombinant bovine leptin and synthetic oligopeptides corresponding to the amino acid sequence $21-40$ and $91-110$ of bovine leptin. Recombinant bovine leptin was raised in the 293 cells and purified from $10 \mathrm{~L}$ of conditioned medium and utilized for immunization. The synthetic peptides were conjugated with keyhole limpet hemocyanin and inoculated into rabbits for antibody generation. Antibody titer was monitored by enzymeimmunoassay, immunoblotting and sandwich binding assay techniques. Each of the antisera, against three different antigens, was found to react with bovine leptin. The titers of anti-peptide antisera were lower than that of anti-recombinant leptin antiserum. Since anti-recombinant leptin antiserum was not neutralized by the leptin peptides $21-40$ and 91-110, it is suggested that each antiserum recognizes a distinct epitope. In immunoblot analyses, all antisera exhibited crossreactivity with human and mouse leptins. However, in the sandwich binding assay, the combination of anti-peptide antisera and anti-recombinant leptin antiserum, originated from bovine leptin, did not cross-react with either human or mouse leptin. The discrepancy of antigenic recognition between the immunoblot analyses and sandwich assay is thought to be dependent on the conformational status of leptin molecules between the species. The antisera generated in this study, which recognized distinct epitopes of bovine leptin, will provide a useful tool for studies of bovine leptin functions.
\end{abstract}

Key words: Anti-peptide antibody, Bovine leptin, Recombinant protein

(J. Reprod. Dev. 50: 717-724, 2004)

$\mathbf{L}$ eptin, the $16-\mathrm{kDa}$ protein of the $o b$ gene, is principally expressed by white adipocytes [1]. Secreted leptin enters the systemic circulation and reaches the central nervous system where it acts as an afferent satiety signal [2]. Leptin regulates food intake resulting in the equilibrium of whole-body energy balance [3]. Interestingly, leptin antagonizes the effects of fasting on reproductive functions [4]. Recent studies have shown that leptin is one of the most critical mediators of nutritional status. In domestic ruminants, leptin has been shown to be one of the most important factors in the regulation

Accepted for publication: August 6, 2004

Correspondence: T. Takahashi (e-mail: tatoru@affrc.go.jp) of energy balance $[5,6]$. Serum leptin concentrations are known to correlate with marbling score, fat depth and quality grade in the beef carcass [7]. Additionally, in dairy cows, serum leptin concentrations are closely associated with energy balance during lactation [8]. Furthermore, it has been shown that plasma leptin levels are negatively correlated with the duration of postpartum anestrus in high-yielding dairy cows [9].

Circulating leptin concentration has been determined by enzymeimmunoassay (ELISA) [10] and radioimmunoassay (RIA) [11]. However in ruminants, the assaying of leptin has not been widespread because of the limited availability of 
convenient assay procedures. Ma et al. [12] developed a multi-species leptin assay method based on the human leptin assay. This multispecies assay technique is now commercially distributed [13]. Although several leptin determinations using commercial multi-species kits have been reported in sheep [14] and cows [15], the results have suggested that this method is not suitable for reliable and accurate quantification because of the weak antibody specificity for ruminant leptin [16]. Earlier attempts to generate high titer antibodies against bovine/ovine leptin in rabbits were not successful, so the male emu (Dromaius novaehollandiae) and female chickens (Gallus domesticus) were used for immunization because of their phylogenic distance from mammals $[17,18]$. The use of these exotic antisera in immunoassay might be inconvenient because of the limited availability of secondary antibodies. Although same efforts to generate rabbit antiserum against bovine/ovine leptin have been reported, those antisera were used for radioimmunoassay at dilutions of 1:300-1500 because of their insufficient titers and specificities [16, 19]. Thereafter a sensitive immunoassay for ovine leptin was established by using the combination of antisera derived from the chicken and rabbit [20].

To obtain a better knowledge of bovine leptin functions, it is necessary to generate reliable antiserum in rabbits and establish the specific immunoassay. The objectives of this study were to generate and characterize antisera against recombinant bovine leptin and synthetic peptides corresponding to the amino acid sequence of bovine leptin for developing a homologous immunoassay in the bovine.

\section{Materials and Methods}

\section{General reagents and methods}

Recombinant mouse and human leptins were purchased from Bio Vendor Laboratory Medicine Inc (Brno, Czech Republic). Anti-mouse leptin antibody was purchased from Calbiochem ( $\mathrm{La}$ Jolla, CA, USA). The human fetal kidney cell line (293 cells, ATCC CRL 1573) used as a host for the recombinant expression was obtained through the American Type Culture Collection and cultured routinely with DMEM/F12 (Sigma, St. Louis, MO, USA) containing $10 \%$ fetal bovine serum (FBS,
Sigma), streptomycin (50 mg/L, Sigma) and penicillin G (100,000 IU/L, Sigma). Polymerase Chain Reaction (PCR) and DNA sequencing were performed by using Mini Cycler (MJ Research, Reno, NV, USA) and ABI prism 373 (Perkin Elmer, Boston, MA, USA), respectively.

\section{Recombinant expression and purification of bovine leptin}

Subcutaneous fat was collected from Japanese Black cattle that has been slaughtered at a local abattoir. Total RNA was isolated with ISOGEN (Nippon Gene, Tokyo, Japan) according to the manufacturer's instruction. Reverse transcription was carried out with $5 \mu \mathrm{g}$ of total RNA using the Superscript II Preamplification System (Invitrogen, Carlsbad, CA, USA).

The bovine leptin cDNA was amplified by RTPCR with high-fidelity thermostable DNA polymerase (Pfu polymerase, Stratagene, La Jolla, CA, USA) and forward (sense) and reverse (antisense) primers corresponding to the nucleotide sequences coding for the regions of bovine leptin (GenBank, U50365; sense primer, 35 bases long, agtatcactagtatgcgctgtggacccctgtatcg; antisense primer, 34 bases long, tacttatctagaaggtttcttcctggac tttgg). The cycling parameters were as follows: 95 $\mathrm{C}$ for $1 \mathrm{~min}, 60 \mathrm{C}$ for $1 \mathrm{~min}$ and $72 \mathrm{C}$ for $1 \mathrm{~min}(30$ cycles). The identity of the PCR product was confirmed by sequencing, after subcloning into pBluescript SK (+) (Stratagene). A Hind III/Not I digest of the $0.6 \mathrm{~kb}$ cDNA fragment containing the region coding for bovine leptin was ligated into an pRcRSV expression vector (Invitrogen) using a ligation kit (TaKaRa, Kyoto, Japan), and then transformed into XL-1 Blue supercompetent cells (Stratagene). The bovine leptin-pRcRSV expression vector was linearized by the digestion of the $B g l$ II restriction endonuclease (TaKaRa) prior to transfection. Approximately $4 \mu \mathrm{g}$ of linearized construct were transfected into $5 \times 10^{5}$ host cells using Lipofectamine Reagent (Invitrogen). Transfected cells were selected with $0.5 \mathrm{mg} / \mathrm{ml}$ of G418 (Invitrogen) over a two-week period. Expression of the recombinant bovine leptin in serum-free medium was detected with immunoblotting using anti-mouse leptin antiserum (1:1000 dilution). Immunoblot analyses were carried out as previously reported [21]. For rising recombinant leptin, the surviving cells were transferred to spinner flasks and cultured in serum- 
free expression medium (293 SFM II, Invitrogen) containing $50 \mathrm{mg} / \mathrm{L}$ of G418 for one week prior to harvesting the medium. Ten liters of harvested media were stored at $-20 \mathrm{C}$ prior to purification.

\section{Preparation of recombinant bovine leptin}

The conditioned medium with bovine leptinpRcRSV-293cells was thawed and centrifuged at $1600 \times \mathrm{g}$ for $60 \mathrm{~min}$ to remove particulate material. The supernatant was concentrated and dialyzed with $20 \mathrm{mM}$ Tris buffer ( $\mathrm{pH}$ 7.8) using tangential flow ultrafiltration apparatus (Pellicon II, Millipore Bedford, MA, USA) and a regenerated cellulose filter with a cut-off below a molecular weight of 10 $\mathrm{kDa}$. Concentrated medium was charged to a DEAE Sepharose ion exchange column $(2.5 \times 18 \mathrm{~cm}$, Amersham Pharmacia Biotec, Buckinghamshire, UK) equilibrated with $20 \mathrm{mM}$ Tris ( $\mathrm{pH} 7.8$ ), and then washed with the same buffer to remove unbound proteins. Recombinant bovine leptin was eluted with $20 \mathrm{mM}$ Tris (pH 7.4) containing $50 \mathrm{mM}$ $\mathrm{NaCl}$. Following chromatography, the presence of bovine leptin in the fraction was determined by immunoblotting.

The immunopositive fractions of the DEAE eluates were pooled, concentrated and dialyzed against a buffer containing $25 \mathrm{mM}$ Tris and $192 \mathrm{mM}$ glycine ( $\mathrm{pH}$ 8.3). The buffer-exchanged sample was further purified by preparative electrophoresis using Mini-prep cell (Bio Rad, Hercules, CA, USA) according to the manufacturer's instruction. The presence of bovine leptin in the fractions was determined by immunoblotting. The immunopositive fractions identified from the preparative electrophoresis were pooled and concentrated, and the protein content measured. This preparation was used as a purified leptin for both immunization and binding assay.

\section{Peptide synthesis}

Two peptides (10 mg each) corresponding to 2140 (INDISHTQSVSSKQRVTGLDC) and 91-110 (AASKSCPLPQVRALESLESLC) of the amino acid sequence of bovine leptin were synthesized and purified to $90 \%$ homogeneity with HPLC. The rationale for peptide synthesis was based on the relative hydrophilicity and flexibility of the region analyzed by a computer program [22]. The peptides were coupled with keyhole limpet hemocyanin (KLH) using m-maleimidobenzoyl-Nhydroxysuccinimide ester through the cysteine residue that was added to the amino terminus for rising antibodies.

\section{Immunization}

Antibody generation was performed by the QIAGEN (Tokyo, Japan). Briefly, adult Japanese White rabbits were used for immunization. The rabbits were bred prior to immunization to collect pre-immune serum. Initially, $0.2 \mathrm{mg}$ of either peptide-KLH complex or recombinant bovine leptin were injected intra-dermally to the rabbits with Freund's complete adjuvant. Quintuple booster immunizations, with $0.2 \mathrm{mg}$ of antigen and Freund's incomplete adjuvant, were given to the rabbits subcutaneously every two weeks following the initial immunization. Immunizations were administrated to the rabbits in the back and neck. Animals were bred a week after second and forth booster injections to determine titers. The titer of each antiserum was determined by ELISA as previously reported [23]. Briefly, 96-well microtiter plates were pre-coated with $500 \mathrm{ng} /$ well of immunized peptides or recombinant bovine leptin. Serially diluted antisera were added to the well of plates and incubated. After twice washing of plates, anti-rabbit IgG conjugated with horseradish peroxidase was added and further incubated. The titer of antisera was visualized by the addition of substrate for horseradish peroxidase. A week after the final booster injection, rabbits were exsanguinated under deep anesthesia. Harvested sera were titered by ELISA and stored at $-30 \mathrm{C}$ following the addition of $0.1 \%$ sodium azide as a preservative. The antigenic specificity of generated antisera was determined by immunoblotting as previously reported [21]. All antisera were used at 1:1000 dilutions for immunoblotting.

\section{Sandwich binding assay}

Anti-peptide antisera against the synthetic peptides, 21-40 and 91-110, of bovine leptin were purified using Affigel protein A affinity chromatography (Bio Rad). Purified IgG fractions from both of the antisera were combined in equal quantities of IgG. The antisera mixture was diluted to $0.5 \mu \mathrm{g} / \mathrm{ml}$ with $0.1 \mathrm{M}$ phosphate buffer $\mathrm{pH} 7.4$ and $100 \mu \mathrm{l}$ aliquot was coated to the wells of 96-well microtiter plate (269620, NUNC, NY, USA).

Anti-recombinant bovine leptin antibody was purified using the same procedure as described above for purification of anti-peptide antisera. The 


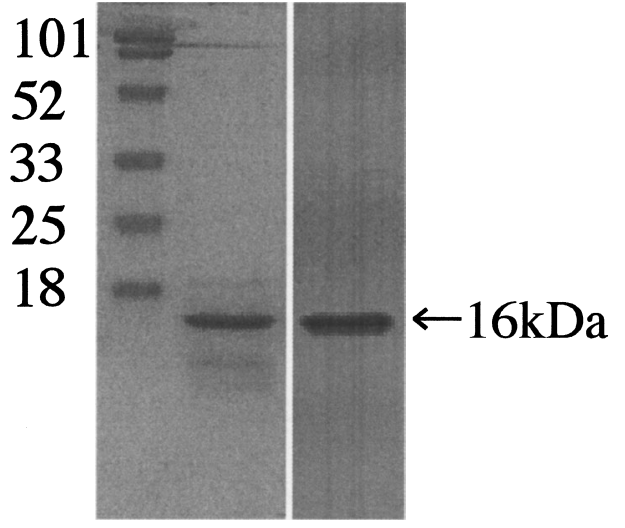

(A) (B)

Fig. 1. Recombinant bovine leptin produced by transfected 293 cells. (Lane A) Purified recombinant bovine leptin $(0.5$ $\mu \mathrm{g})$ was applied to the sodium dodecyl sulfate polyacrylamide gel electrophoresis (SDS-PAGE) and stained with Coomassie brilliant blue. (Lane B) Purified recombinant leptin $(0.25 \mu \mathrm{g})$ was applied to SDS-PAGE and transferred onto polyvinylidene difluoride (PVDF) membrane. Blot was probed with anti-mouse leptin antibody. Recombinant bovine leptin was detected as a 16-kDa protein. Molecular standards (kDa) are shown.

purified IgG fraction was labeled with Europium as a tracer using a Eu-labeling kit (Wallac, Turku, Finland) according to the manufacturer's instructions. A series of reference standards were prepared by the diluting purified recombinant leptin with charcoal-treated cow serum. The charcoal-treated cow serum was prepared as previously described [24]. Serially diluted reference standards $(100 \mu \mathrm{l})$ and assay buffer (200 $\mu l)$ were dispensed into the antibody-immobilized microtiter plate. The plate was incubated overnight at room temperature and then washed six times. Europium-labeled anti-leptin antibody (250 ng of IgG/0.1 ml/well) was added and further incubated under the same conditions as previous incubation. The plate was washed again and supplemented with enhancement solution $(200 \mu \mathrm{l})$. Fluorescence detection was carried out using a Wallac Fluorometer Model 1234 (Wallac) after 5 min of enhancement.
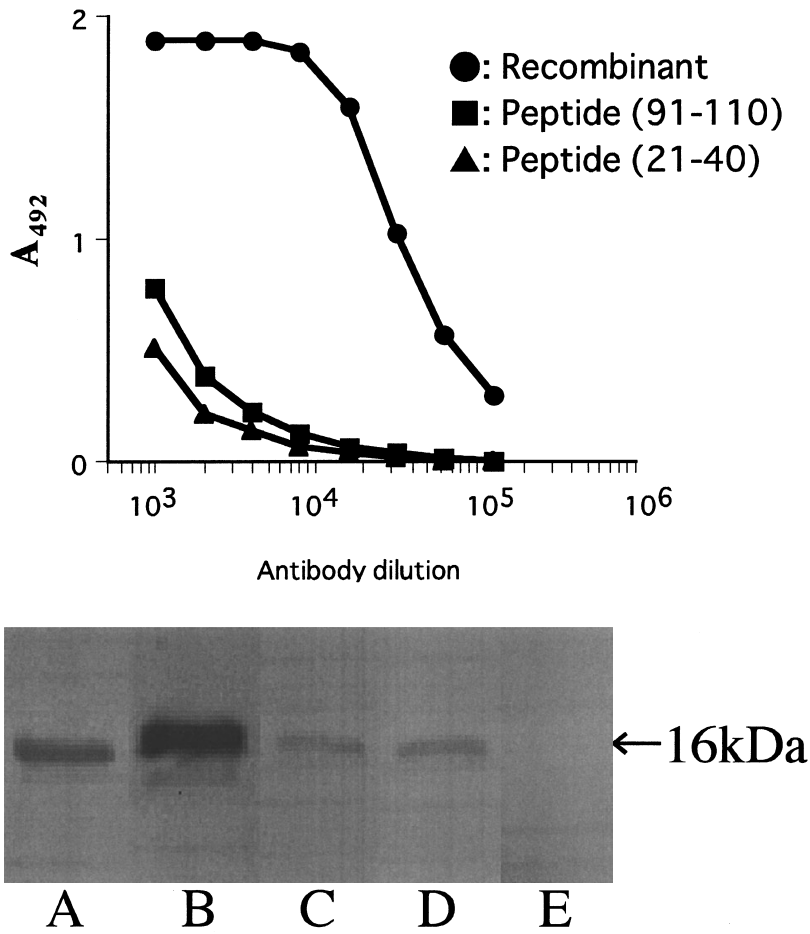

Fig. 2. (A) Antibody titration by ELISA. (B) Recombinant bovine leptin $(0.5 \mu \mathrm{g})$ was run on the SDS-PAGE, blotted on the PVDF membrane and probed with antimouse leptin antibody (lane A), anti-bovine leptin antibody (lane B), anti-leptin peptide 21-40 (lane C), anti-leptin peptide 91-110 (lane D) and non-immune rabbit serum (lane E).

\section{Results}

The 293 cells transfected with bovine leptinpRcRSV expression vector expressed a $16-\mathrm{kDa}$ protein that was recognized by anti-mouse leptin antibody (Fig. 1). Approximately $2 \mathrm{mg}$ of protein was purified from the $10 \mathrm{~L}$ of conditioned medium with transfected 293 cells.

The antiserum against peptides and recombinant leptin showed reactivity with the immunized antigen (Fig. 2-A). However antisera varied considerably in titers, especially between the antipeptide antisera and anti-recombinant leptin antiserum. The titers of anti-peptide 21-40 and 91110 antisera with 1:1000 dilutions were equivalent to those of the anti-recombinant leptin antiserum at dilutions of 1:80000 and 1:50000 respectively. All antisera showed reactivity to recombinant leptin in the immunoblot analyses (Fig. 2-B). Additionally, all antisera cross-reacted with human and mouse 

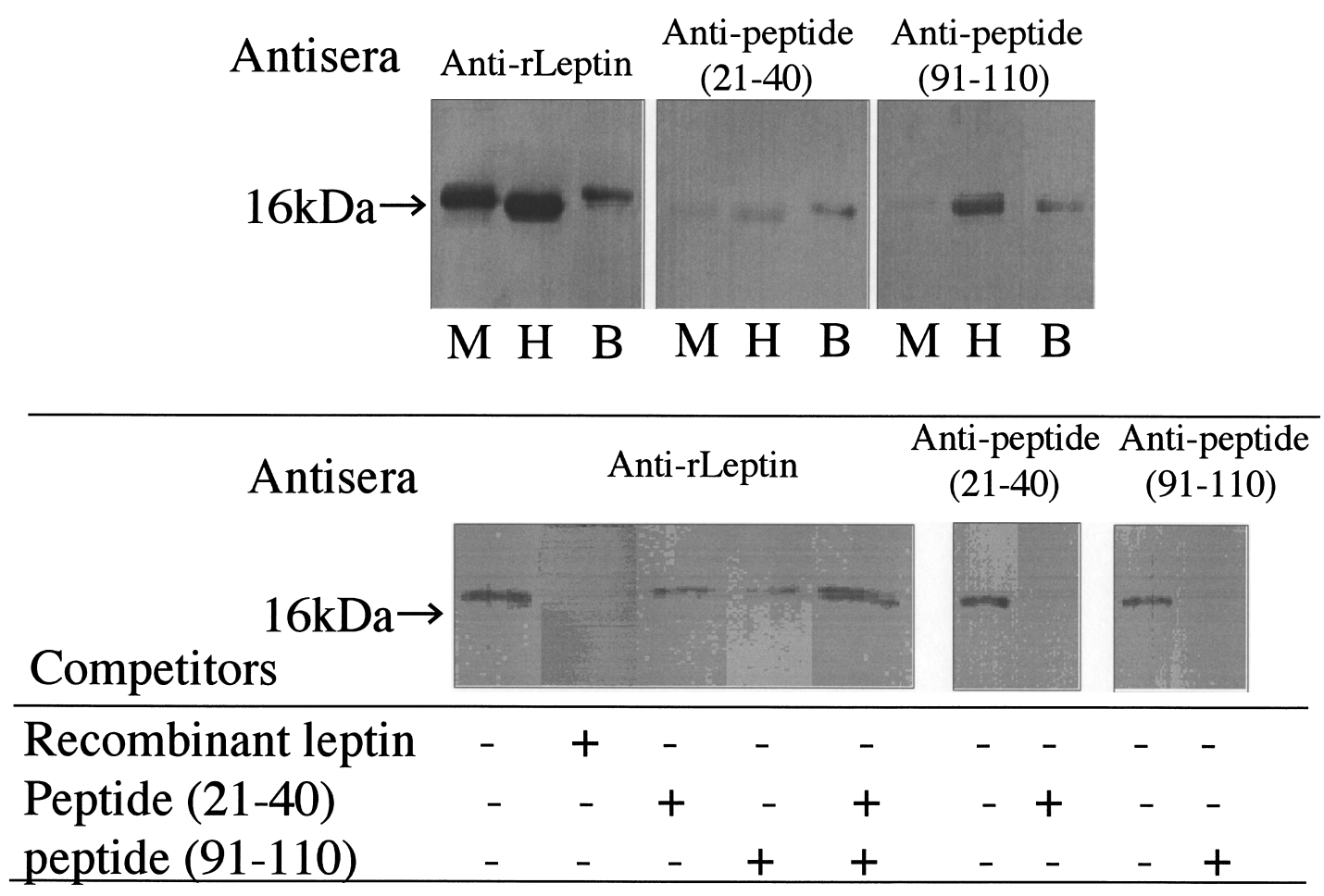

Fig. 3. (A) Cross-reactivity of antisera. Mouse (M), human (H) and bovine (B) leptins $(0.5 \mu$ g each) were run on the SDS-PAGE, blotted on the PVDF membrane and probed with either anti- 21-40, 91-110 peptide antisera or anti-recombinant leptin (anti-rLeptin) antiserum. (B) Competitive neutralization of antibodies by the antigens used for immunization. Antisera were preincubated with or without excess amount of antigen $(100 \mu \mathrm{g} / \mathrm{ml})$ prior to probing.

leptins (Fig. 3-A). The immunopositive bands on the blot with anti-recombinant leptin antiserum were more intensive than those of other blots with anti-peptide antisera. These findings coincided with the results of antibody titration by ELISA. Although all antisera were neutralized by a prior incubation with immunized antigens (Fig. 3-B), the anti-recombinant leptin antiserum was not neutralized by the leptin peptides (amino acids 2140, 91-110).

The results of the binding assay showed that the addition of recombinant leptin increased the fluorescence count in a dose-dependent manner (Fig. 4). Attempts to duplicate the dose-dependent binding with human and mouse leptins revealed an apparent lack of cross-reactivity at a dose of 12.8 ng. The correlation of dose-response curves between the reference standards and the serially diluted cow plasma was almost parallel as shown in Fig. 4.

\section{Discussion}

Our results indicate that recombinant leptin was successfully expressed in 293 cells and allowed the generation of anti-leptin antiserum in the rabbit. We also generated anti-peptide antisera against amino acid residues $21-40$ and $91-110$ of bovine leptin. However, the ELISA and immunoblot analyses showed relatively weak titers of antipeptide antisera compared to that of antirecombinant leptin antiserum. The titer of antipeptide antiserum is likely to depend on the selected rationale of the amino acid sequence of the target protein and antigenic activity of immunogenic compound after conjugation to the carrier molecules. It was hypothesized that under the native folding condition of bovine leptin, amino acids $21-40$ and 91-110 would be useful for antigen determination, but these would not be optimal for production of high-titer antisera.

In the present study, we tested a prototype of sandwich immunoassay for bovine leptin by using 


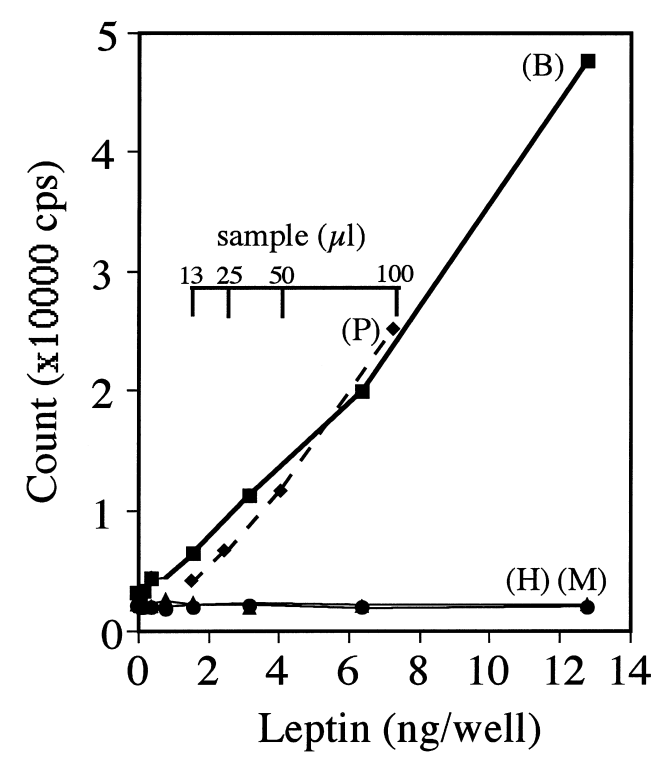

Fig. 4. Sandwich binding assay with the combination of solid-phase anti-peptide antisera and Europium-labeled antirecombinant leptin antiserum. Serially diluted recombinant bovine (B), mouse (M) and human $(\mathrm{H})$ leptins, and cow plasma (P) were tested for dosedependent binding to the antisera.

recombinant leptin and its antisera. At present, a multi-species leptin assay kit based on the human leptin assay is commercially available [12]. Several procedures for assaying of bovine/ovine leptin have been reported [16-20]. However, they have some disadvantages: (a) except ref. 18, they use radiological material; and (b) they have insufficient reliabilities. Ehrhardt et al. [19] have reported that the application of multi-species RIA kit for sheep/ cattle samples resulted in low and unresponsive values of plasma concentration under changes in nutrition or adiposity. Ma et al. [12] have reported that the blank control with no specimen showed a certain amount $(<1 \mathrm{ng} / \mathrm{ml})$ of leptin by the multispecies RIA kit. Since the RIA kit is based on the double-antibody method, these false-positive estimates are likely to be caused by an unknown plasma factor interacting with the primary antibody. To solve this problem, Imagawa et al. [10] developed a sandwich ELISA for assaying human leptin. The sandwich assay requires two distinct antibodies with different antigenic recognition for capture and signal. This assay system has improved specificity and sensitivity. Since antirecombinant leptin antiserum is not neutralized by the leptin peptides $21-40$ and 91-110, it has been suggested that this antiserum recognizes an epitope other than amino acids 21-40 and 91-110. Such characteristics are essential for establishing the sandwich assay. In the present study, the mixtures of anti-peptide antisera 21-40 and 91-110 were utilized for the solid-phase antibody in the assay. In preliminary experiments, the anti-peptide antiserum showed insufficient activity in capturing leptin when immobilized individually (data not shown). The combination of anti-peptide antisera and anti recombinant leptin antibody was successfully used for leptin assay using sandwich assay method.

The time-resolved fluoroimmunoassay (TR-FIA) employs lanthanide elements as tracers. Since the fluorescent activity of the lanthanide tracer is free from radiological decay, this system has a great advantage over RIA [24]. However it should be kept in mind that direct plasma immunoassays are sometimes affected by unknown factors present in the plasma [25]. This has resulted in incorrect assay values when compared to the data of mock samples constituted with the assay buffer and leptin. To overcome this problem, matrices of the standards and samples have to be simulated. In the present study, the sandwich assay was carried out using a reference standard that was processed with charcoal-treated cow serum. Since it has been reported that the charcoal treatment could eliminate leptin from human plasma [10], charcoaltreated cow serum could be utilized for preparing reference standards of bovine leptin.

The antisera generated in this study cross-reacted with mouse and human leptins in the immunoblot analyses. However in the binding assay, the results showed that the combination of antisera did not cross-react. It should be noted that there were sodium dodecyl sulfate (SDS) and 2mercaptoethanol denatured proteins in the SDSpolyacrylamide gel electrophoresis prior to immunological probing. Under non-denaturing conditions in the binding assay, subtle differences in the conformational status among the different leptins are likely to affect the accessibility of antibody to the epitope.

In conclusion, we generated a series of antisera recognizing distinct epitopes for studying the biology of bovine leptin. The amino acid sequences 
21-40 and 91-110 were shown to be at least a part of an epitope for bovine leptin. In the present study, a prototype sandwich TR-FIA is proposed for assaying bovine leptin. However the sensitivity, accuracy and reproducibility should be further validated for assays of plasma specimens in bovine. The discrepancy of antigenic recognition between the immunoblot analyses and binding assay might be due to the conformational status of leptin molecules between the species.

\section{Acknowledgements}

This study was supported by the grants-in-aid from ORCS, BRAIN and MAFF (HC-04-2261-2) Japan. The authors thank Mrs. S. Hamanaka for technical assistance in binding assay experiments.

\section{References}

1. Zhang $\mathbf{Y}$, Proenca $R$, Maffei M, Barone M, Leopold L, Friedman JM. Positional cloning of the mouse obese gene and its human homologue. Nature 1994; 372: 425-432.

2. Lonnquist F, Arner P, Nordfors L, Schalling M. Overexpression of the obese (ob) gene in adipose tissue of human obese subjects. Nat Med 1995; 1: 950-953.

3. Levin N, Nelson C, Gurney A, Vandlen R, de Sauvage $F$. Decreased food intake does not completely account for adiposity reduction after ob protein infusion. Proc Natl Acad Sci U S A 1996; 93: 1726-1730.

4. Schneider JE, Zhou D, Blum RM. Leptin and metabolic control of reproduction. Horm Behav 2000; 37: 306-326.

5. Amstalden M, Garcia MR, Williams SW, Stanko RL, Nizielski SE, Morrison CD, Keisler DH, Williams GL. Leptin gene expression, circulating leptin, and luteinizing hormone pulsatility are acutely responsive to short-term fasting in prepubertal heifers: relationships to circulating insulin and insulin-like growth factor I (1). Biol Reprod 2000; 63: 127-133.

6. Keisler DH, Daniel JA, Morrison CD. The role of leptin in nutritional status and reproductive function. J Reprod Fertil (Suppl) 1999; 54: 425-435.

7. Geary TW, McFadin EL, MacNeil MD, Grings EE, Short RE, Funston RN, Keisler DH. Leptin as a predictor of carcass composition in beef cattle. J Anim Sci 2003; 81(1): 1-8.

8. Reist M, Erdin D, von Euw D, Tschuemperlin K, Leuenberger $\mathrm{H}$, Delavaud C, Chilliard Y, Hammon HM, Kuenzi N, Blum JW. Concentrate feeding strategy in lactating dairy cows: metabolic and endocrine changes with emphasis on leptin. J Dairy Sci 2003; 86: 1690-1706.

9. Kadokawa H, Blache D, Yamada Y, Martin GB. Relationships between changes in plasma concentrations of leptin before and after parturition and the timing of first post-partum ovulation in high-producing Holstein dairy cows. Reprod Fertil
Dev 2000; 12: 405-411.

10. Imagawa $\mathbf{K}$, Matsumoto $\mathbf{Y}$, Numata $\mathbf{Y}$, Morita A, Kikuoka S, Tamaki M, Higashikubo C, Tsuji T, Sasakura $K$, Teraoka $H$, Masuzaki $H$, Hosoda $K$, Ogawa Y, Nakao K. Development of a sensitive ELISA for human leptin, using monoclonal antibodies. Clin Chem 1998; 44: 2165-2171.

11. McGregor GP, Desaga JF, Ehlenz K, Fischer A, Heese F, Hegele A, Lammer C, Peiser C, Lang RE. Radiommunological measurement of leptin in plasma of obese and diabetic human subjects. Endocrinology 1996; 137: 1501-1504.

12. Ma Z, Gingerich RL, Santiago JV, Klein S, Smith CH, Landt M. Radioimmunoassay of leptin in human plasma. Clin Chem 1996; 42: 942-946.

13. Paolucci M, Rocco M, Varricchio E. Leptin presence in plasma, liver and fat bodies in the lizard Podarcis sicula: fluctuations throughout the reproductive cycle. Life Sci 2001; 69: 2399-2408.

14. Bocquier F, Bonnet $\mathbf{M}$, Faulconnier $\mathbf{Y}$, GuerreMillo M, Martin P, Chilliard Y. Effects of photoperiod and feeding level on perirenal adipose tissue metabolic activity and leptin synthesis in the ovariectomized ewe. Reprod Nutr Dev 1998; 38: 489498.

15. Chilliard Y, Bonnet M, Delavaud C, Faulconnier Y, Leroux C, Djiane J, Bocquier F. Leptin in ruminants. Gene expression in adipose tissue and mammary gland, and regulation of plasma concentration. Domest Anim Endocrinol 2001; 21: 271295.

16. Delavaud C, Bocquier F, Chilliard Y, Keisler DH, Gertler A, Kann G. Plasma leptin determination in ruminants: effect of nutritional status and body fatness on plasma leptin concentration assessed by a specific RIA in sheep. J Endocrinol 2000; 165: 519-526.

17. Blache D, Tellam RL, Chagas LM, Blackberry MA, Vercoe PE, Martin GB. Level of nutrition affects leptin concentrations in plasma and cerebrospinal fluid in sheep. J Endocrinol 2000; 165: 625-637.

18. Kauter K, Ball M, Kearney P, Tellam R, McFarlane JR. Adrenaline, insulin and glucagon do not have 
acute effects on plasma leptin levels in sheep: development and characterisation of an ovine leptin ELISA. J Endocrinol 2000; 166: 127-135.

19. Ehrhardt RA, Slepetis RM, Siegal-Willott J, Van Amburgh ME, Bell AW, Boisclair YR. Development of a specific radioimmunoassay to measure physiological changes of circulating leptin in cattle and sheep. J Endocrinol 2000; 166: 519-528.

20. Thomas L, Wallace JM, Aitken RP, Mercer JG, Trayhurn P, Hoggard N. Circulating leptin during ovine pregnancy in relation to maternal nutrition, body composition and pregnancy outcome. J Endocrinol 2001; 169: 465-476.

21. Takahashi T, Aso H, Hashizume K. Immunological and biological activities of bovine placental lactogen in placental explant culture. J Reprod Dev 2001; 47: 63-67.
22. Kyte J, Doolittle RF. A simple method for displaying the hydropathic character of a protein. $J$ Mol Biol 1982; 157: 105-132.

23. Deb S, Hashizume $K$, Boone $K$, Southard JN, Talamantes F, Rawitch A, Soares MJ. Antipeptide antibodies reveal structural and functional characteristics of rat placental lactogen-II. Mol Cell Endocrinol 1989; 63: 45-56.

24. Meurman OH, Hemmila IA, Lovgren TN, Halonen PE. Time-resolved fluoroimmunoassay: a new test for rubella antibodies. J Clin Microbiol 1982; 16: 920 925.

25. Takahashi T, Hamanaka S, Hashizume $K$. A direct time-resolved fluorescent immunoassay (TR-FIA) for measuring plasma progesterone concentration in the sika doe (Cervus Nippon centralis). J Reprod Dev 2001; 47: 119-123. 